\title{
Interest representation in the EU: an open and structured dialogue?
}

\author{
GREENWOOD, J.
}

2019 


\title{
Interest Representation in the EU: an open and structured dialogue?
}

\author{
Justin Greenwood
}

\section{Introduction}

Since 1992 the European Commission has been in search of an 'open and structured dialogue with special interest groups' (Official Journal, 1993, p.2). The structured dialogue is as much for the benefit of EU institutions as it is a means for outside interests to engage with them, providing a plurality of technical and political information, a reservoir of potential allies to achieve the goals of different EU institutions viz. each other and with member states, and some degree of refuge from populist criticism about a dialogue with lobby groups and their representatives (see Freeman and Dolan, this volume). In 2001, it became cast more widely as a dialogue with 'civil society' as a means to provide greater legitimacy to EU policy-making (European Commission, 2001). A search for legitimacy for the technical content of policy ('output legitimacy') and by way of participation in the formulation of policy ('input' legitimacy) has led to the design of a series of procedures ('throughput legitimacy'; Schmidt, 2012) to structure this dialogue (see also Kröger, this volume). The procedures anticipate engagement in the dialogue primarily by organisations, underpinned by incentivised transparency mechanisms. Collectively, the various procedures for an open and structured dialogue help to provide EU institutions with a 'market place of ideas' from which to choose for policy making purposes, as well as the means to identify and select allies during the course of legislative proposals. EU institutions also utilise advocacy organisations as an ‘unofficial opposition’ (see Cann and da Silva, this volume) in a political system which is otherwise highly focused on consensus building.

Organised civil society in the form of advocacy organisations are frequently used by international organisations as the best available proxy for an otherwise disengaged civil society, because of the absence or weakness of mechanisms linking their political institutions directly to civil society. At EU level, citizens are linked to EU decision making indirectly through their elected governments in the Council of Ministers, and directly through the European Parliament (EP). The limitations of the 
direct linkage is reflected in voting turnout in EP elections, with the last two each producing an average turnout close to $43 \%$ (including countries with compulsory voting). The absence of a European 'demos', or public space, is held to originate in the absence of a common language, media (Scharpf, 1998 in van de Steeg, 2010), or recognisable political parties, and no system of government and opposition. These structural limitations mean that EU institutions, like other international organisations sharing similar constraints, use organised interests as the best available proxy for civil society, with a nucleus satelliting around the EU institutions in Brussels (the 'Brussels bubble’), but with procedures increasingly cast at securing wider participation. There is a debate as to whether these procedures simulate political competition and contestation by a wide range of participants, or constrain civil society organisations by forcing them to operate within the confines of EU institutions (Kohler Koch, 2012). In this latter view, contestation provides the essence of politics, whereas the inward looking, consensus orientation of decision making in international organisations (around 80\% of the Commission's legislative proposals become law Woll, 2012) make them unsuited in principle to democratic legitimacy (Kohler Koch, 2012). Kohler Koch is also critical of the elite nature of EU professionalised lobby groups and the uneven nature of political participation which hardly provides for equal citizen participation, as well as finding patchy implementation of procedures for participation (Kohler Koch \& Quittkat, 2013). Others who share the perspective of the importance of contestation find it present in the growing engagement of social movements outside of the 'Brussels bubble' in EU legislative files (Crespy, 2014; Dür and Mateo, 2014; Leiren \& Parks, 2014; Parks, 2014; see also Eliasson, this volume). There are also contentious organisations operating within the Brussels bubble, such as the Corporate Europe Observatory (CEO) (see Cann and da Silva, this volume), sharing back-office facilities with other like-minded organisations in an eco-building 'palace of protest,' a short walk away from the European Parliament, with an atmosphere reminiscent of a 'well run student union' (Ariès \& Panichi, 2015). Campaigns related to internet freedom have notably involved social movements utilising online campaigning skills, extending far beyond the 'Brussels bubble'.

Whilst the total population of organisations seeking to influence the public policy of EU institutions, and the number of individuals involved, can never be known with any precision, the EU Transparency Register contains almost 10,000 
organisations across the globe which have chosen to make an entry (two-thirds of which identify 'European’ as their level of organisation - Greenwood \& Dreger, 2013), including over 6,000 individuals with accreditation to access the European Parliament on a regular basis. The register contains different sections for: consultancies; law firms; business associations; companies; trade unions; Nongovernmental organisations (NGOs); think tanks and related organisations; religious organisations; and regional authorities, public and mixed entities. The Transparency Register is described in further detail later in this chapter.

The fragmented nature of EU decision making provides for a naturally pluralistic environment. The diversity of each of the three main legislative bodies insulates EU decision making from 'regulatory capture', with 28 member states, 8 political parties in the European Parliament (EP), and over 30 different departments (Directorates General) in the European Commission. In consequence, this breadth requires the formation of broadly based alliances and platforms from civil society organisations (see the chapters by von Westernhagen, and Stachowicz, this volume). The Marine Stewardship Council is an example of a common platform (in this case between Unilever and the Worldwide Fund for Nature ((WWF)) providing certification for products drawn from sustainable fisheries, helping to position a multinational company with fish food branded products as part of the solution rather than part of the problem. The diversity of EU decision making requires any single interest to dilute its demands in a consensus orientated system. Klüver et al find that the size of lobbying coalitions is a good predictor of interest group success, with broadly based large coalitions enjoying an advantage (Klüver, Braun and Beyers 2015). NGOs, in particular, act in coalition, often with success in influencing policy outcomes by politicising issues and bringing them to a wider audience, as described later in this chapter.

\section{The Dialogue Procedures}

The dialogue procedures emerged from a bifocal process in 2001. One was a drive for 'better regulation', spearheaded by the high level Mandelkern Report with its critique of the quality of policy outputs from the European Commission (Mandelkern 
Report, 2001). The second was the Commission's own White Paper on Governance in the same year, with its emphasis on input (participative) legitimacy. These two strands remain prominent to the present, although commentators differ as to where the emphasis most lies. The quality and significance of the procedures which developed following these measures is the subject of debate in the literature on interest representation.

\section{Funding}

Funding by EU institutions makes it possible for a wide variety of interests from civil society to maintain professionalised organisations in Brussels geared to dialogue with them, providing a plurality of presence. Non-Governmental Organisations (NGOs) s in receipt of EU grants receive an average of $43 \%$ of their income in this way (Greenwood and Dreger, 2013). Many of the core European umbrella groups, such as the Platform of European Social NGOs ('Social Platform'), as well as those in the fields of homelessness and public health, are the direct result of intervention by EU institutions in search of informed dialogue partners, and allies for regulatory legislative initiatives (Kohler Koch, 2012). The Social Platform receives over $80 \%$ of its income from an EU grant.

Recipients differ in the way they perceive their EU funding (Jacquot and Vitale, 2014). Thus, the European Women's Lobby (funded almost $80 \%$ by the European Commission) has taken a policy decision not to take disputes with the European Commission to court, whereas the European Environmental Bureau (funded around $40 \%$ by an EU grant) have taken contention with the Commission to law (Sanchez Salgado, 2014; see also Buijink, this volume). Larger global brand NGOs, such as Amnesty International and Greenpeace, have taken policy decisions not to seek EU funding on the grounds that it might be perceived to compromise their independence. A counter example is provided by Friends of the Earth Europe (FoEE) who received over €6million in EU funding in 2014, and yet any cursory glance at its website $^{\mathrm{i}}$ reveals substantial contention of EU policy making. Transparency International (TI), similarly, have used EU funding to conduct and disseminate reports and activities which are highly critical of EU institutions (Transparency International, 2015; see also Freeman and Dolan, this volume). Highly contentious organisations, 
such as the CEO, have successfully accessed alternative sizeable sources of independent funding from trust foundations.

The search for legislative allies intensified when the agenda of the European Commission shifted during the 1990s and beyond from an earlier period of marketmaking to a new epoch of market regulating (Dür, Bernhagen \& Marshall, 2015). Regulating markets required the Commission to make common cause with supporters for its measures to counter-mobilise against business opposition to legislative proposals expressed through member state governments in the Council of Ministers. Regulatory proposals are likely to produce competitive interest group politics (Young, 2010), either between NGOs and business, or between and within these segments and sectors. For instance, regulation of vehicle emissions by standard setting will divide car component suppliers (with the technology to produce parts which meet high standards) from car manufacturers (seeking to contain costs), and manufacturers of large vehicles (challenged by high standards) from smaller and less polluting vehicles. These differences can come down to the level of the individual firm producing different types of cars (see also Clarat, this volume), and products. For instance, IBM found that one of its product divisions used open-source software whilst another used proprietary software, making it unable to reach a common position on a legislative proposal aimed at making patenting of software easier (Gehlen, 2006). Where a firm, or industry segment, is able to reach a common position which is consistent with that of an EU legislative institution, so alliances will result. These shifting sands of politics provide for a much more nuanced understanding of EU politics compared to caricatures which treat business or NGOs as if they were a homogenous and unified entity. Boräng and Naurin find that

"The common picture of Brussels - and in particular the Commission - of being in the hands of big business is not confirmed by this study. On the contrary, civil society actors are more likely to share views with the Commission officials of what is at stake in legislation compared to business. When competition is low, and a few business actors get to dominate the process and the media, the odds get to even out between the two types of actors” (Boräng and Naurin, 2015, p.514). 
Funding thus provides the EU institutions with a ready network of supporters for legislative purposes.

\section{Transparency}

Transparency regimes vary between access to documentation from EU political institutions, to the transparency of lobbying organisations and their interaction with EU institutions, and transparency in the use of expertise.

\section{(i) Access to Documents}

The EU Access to Documents regime also dates from 2001, providing for access to a wide range of documents (including emails), subject to certain exceptions (such as, inter alia, maintaining the integrity of inspections, audits and investigations). In 2014, the European Commission received 6227 requests for access, making a full disclosure in $73 \%$ of cases and part disclosure of a further 15\% (and subsequently one-fifth of these were fully disclosed on appeal) (European Commission, 2015; see also Kröger, this volume). Dissatisfied applicants can use the appeals procedure, and beyond that complain to the European Ombudsman (see Gadesmann, this volume) or pursue a case in the European Court of Justice. The process is highly politicised, including an NGO (Access Info Europe) dedicated to the cause and an accompanying website to facilitate requests and publish the information obtained, and other activist NGOs (including Transparency International and the CEO) which have made common cause with an activist Ombudsman as a source of pressure to gradually expand the release of documents over time.

\section{(ii) The Transparency Register}

The Register is for groups and organisations with whom EU institutions interact, aiming to provide public information as to what interests are being represented at EU level, who is representing them and through which outlets, what legislative files are being addressed, and how much is spent in the process. Organisations publish an entry themselves on the register, and agree to be bound by an obligatory code of conduct (see Grad and Frischhut, this volume) in order to be included. The Joint Transparency Register Secretariat (JTRS) of the European Commission and European Parliament oversees the register and makes random checks on data as well as unusual entries and data ranges, but in practice much of the monitoring of the register is undertaken by 'watchdog' NGOs such as Transparency International (TI) (see Freeman and Dolan, 
this volume) and the CEO, together with the media outlet Politico with its specialist Brussels Influence newsletter. Inclusion in the register is incentivised by measures such as a pre-condition to meet with a Commissioner or their cabinet, or a Director General of a Commission service. TI have a dedicated website, EU Integrity Watch, which records these meetings from the declarations made by those inside the Commission. In this way, there are regulatory measures to cover the activities of both the lobbied and lobbyists. Other registration incentives for lobbyists include the possibility for a one-year accreditation to the European Parliament (EP) for a day-pass to the premises (making it easier to reach lobbying targets), access to speaking positions in EP hearings, and to the European Commission's expert groups, described below.

The novel feature of the register is its breadth of scope, taking in

"activities carried out with the objective of directly or indirectly influencing the formulation or implementation of policy and decision-making processes of the EU institutions...irrespective of where they are undertaken and the channel or medium of communication used" (Inter Institutional Agreement, para 7; my emphasis).

This breadth of scope helps to explain the quantity of registrations, as well as the information made public. With the notable exception of law firms, watchdog groups now find it hard to identify any entity which is regularly lobbying EU institutions and has no entry on the register. Law firms have historically used 'client confidentiality' as cover not to register as to do so involves disclosure of clients as well as their activities, providing them with a competitive advantage in attracting clients, but even this is now eroding as some national law societies are removing this objection, and some law firms breaking ranks and making a registration. The emphasis of watchdog organisations has shifted to the quality of data in the register (see Freeman and Dolan, this volume), and to extending sanctioning mechanisms which currently rely on reputational measures such as suspension from the register and withdrawal of the pass to the EP. A parallel focus involves measures aimed at the lobbied, and in particular the 'revolving door' phenomenon (see Cann and da Silva, this volume). There are currently restrictions on Commissioners taking up positions within 18 months of 
taking office, and upon senior officials for 24 months extending to 36 months for activities covering their former service. The restrictions on former MEPs are less strict in recognition of electoral fortunes, with a lobbying position resulting in a loss of privileges in using the facilities of the EP which former MEPs are otherwise entitled to. The Ombudsman has also been active on lobby regulation measures, working with NGOs to expand the sphere of regulation (Panichi, 2015; see also Gadesmann, this volume). The case for a mandatory transparency register is made by Krajewski in this volume.

\section{$\underline{\text { Consultation }}$}

The European Commission publishes an annual Commission Legislative Work Programme (CLWP) which alerts stakeholders to an upcoming consultation, and provides a 'consultation road map' as an integrated component of impact assessments. All Commission legislative proposals and major policy initiatives carry the requirement to publish an integrated Impact Assessment, in which consultation forms a compulsory embedded component, to conform with a set of standards embedded in 'soft law' (Smismans and Minto, 2016). A Regulatory Scrutiny Board (RSB) oversees impact assessments, with powers to require unsatisfactory consultations to be changed. The European Ombudsman forms a further independent measure of oversight (Smismans and Minto, 2016). The European Commission's Your Voice in Europe portal is an open consultation outlet for new policy initiatives, publicly open for 12 weeks for commentary. After the 12 weeks, the Commission rounds up the policy responses with an analysis document, and listing the respondents. Mostly, the topics are highly specialised, resulting in a limited number of responses from organisations with technical expertise. There is some patchiness as to the production of these reports (Kohler Koch \& Quittkat, 2013), making accountability difficult.

Some topics for consultation reach a wider public, stimulated by activist organisations providing template responses through online submission portals. Activist organisations play a key role in politicising issues, using powerful frames to simplify technical issues (Boräng and Naurin, 2015). The European Commission’s public consultation on the Investor State Dispute Settlement Mechanism (ISDS) of the Transatlantic Trade and Investment Partnership (TTIP) produced almost 150,000 responses (see Eliasson, this volume). The extent of pressure in some member states, 
notably Germany and France, has politicised TTIP to the point of senior politicians announcing the end of the trade deal at the time of writing (von der Burchard, 2016). NGOs also politicised the Anti-Counterfeiting Trade Agreement (ACTA) to such an extent as to defeat the measure in the European Parliament after the EP had initially been minded to pass the measure, presenting frames suggesting that sharing music files between friends would be criminalised (Dür and Mateo, 2014). And in August 2016, open internet campaigners heralded a major triumph after an EU regulatory body took measures to protect net neutrality, prohibiting Internet Service Providers from blocking or changing the speed of services except under strictly defined conditions (Toor, 2016). Campaigners used their professionalised online skills to attract an EU record of 480,000 responses to the consultation by the Body of European Regulators for Electronic Communications (BEREC). TTIP/ISDS and net neutrality provide powerful examples of the ways in which NGOs and Social Movements can mobilise support and channel it into EU protest using established consultation procedures for 'an open and structured dialogue' with civil society, achieving their intended results.

Organisations with something to say on a consultation topic, either as a core stakeholder or with an unusual position, often get selected to make a presentation in a second phase of public meeting consultation (Broscheid and Coen, 2007). There are differences between the Commission services as to how this second tier of dialogue is organised, as well as different perceptions between institutions and societal actors as to the purpose of consultative meetings, summed up in evaluation reports as 'A Voice but not a Vote' (ECORYS, 2007; Iusman and Boswell, 2016).

\section{Expertise}

The definitive study on the use of expert groups made by the European Commission is provided by Gornitzka and Sverdrup (2015), who found that around 40\% (500) of the Commission's advisory groups featured societal actors, with the remainder comprising national ministries and agencies. Of these, business actors were present in $29 \%$ of groups and NGOs in $28 \%$ of groups, leading them to conclude that

"the overall pattern of inclusion/exclusion of societal actors are partly consistent with a norm of participatory diversity \& representation of heterogeneous 
interests and perspectives...business interests are more often than not matched and mixed with other non-governmental actors” (p.161).

Taken together, these procedures are designed to provide 'an open and structured dialogue' between EU institutions and outside interests. They are constitutionalised by Article 11 of the 2009 Lisbon Treaty, which records (my emphasis) that

- The institutions shall, by appropriate means, give citizens and representative associations the opportunity to make known and publicly exchange their views in all areas of Union action.

- The institutions shall maintain an open, transparent and regular dialogue with their representative associations and civil society.

- The Commission shall carry out broad consultations with parties concerned in order to ensure that Union action is coherent \& transparent.

Article 11 also introduced a new component, the European Citizens' Initiative, in which one million signatories collected within 12 months and drawn from one-quarter of member states (with country quotas by size) can request the European Commission to bring forward a legislative proposal on a subject covered by the EU Treaties, reinforced with a hearing in the Parliament to the response of the European Commission. Thus, it is an agenda-setting measure; whilst the signature collection threshold has proved too challenging for most initiatives, it has served to diversify the range of issues brought to EU institutions by civil society (Bouza Garcia and Greenwood, 2014), and brought campaigning away from Brussels and into the member states (Greenwood and Tuokko, 2016). Often, interests follow policy initiatives introduced by the European Commission, and thus the ECI provides an institutionalised reverse mechanism.

\section{Conclusions}

Taken as a whole, there is a recognisably pluralistic dimension to the interests represented at EU level. The fragmented nature of EU decision making already provides a degree of insulation from pressure by any one type of interest, and this pluralism is reinforced by procedures for the representation of a diverse set of 
interests at EU level, with interests represented in an open public arena. Whilst there are provisions for the European Commission to be answerable for the policy choices it makes on the basis of policy inputs it received, there is unevenness to the extent that it follows accountability arrangements. Nonetheless, NGOs have stimulated the responsiveness of EU institutions where they have been able to raise the saliency of an issue, such that the European Parliament will take up the cause in an effort to demonstrate its legitimacy as the people's tribune. In a striking analysis of 70 legislative files, Dür et al find that business actors are less successful than citizen actors in EU policy making, particularly where NGOs have succeeded in raising the saliency of an issue to the point that the European Parliament takes up the cause (Dür Bernhagen \& Marshall, 2015) (see also Marshall, this volume). Thus, interest group type matters; these authors found that business interests are only successful where conflict is low and issues remain technical and below the radar of public saliency to the EP, a finding echoed by others (Boräng and Naurin, 2015). Klüver et al also place emphasis upon the salience and complexity of an issue in determining interest group activities, as well as factors such as whether a change to the status quo is involved, policy type (regulatory policies producing competitive interest group politics), and the size of lobbying coalitions (Klüver, Braun \& Beyers, 2015). These contextual factors help to produce a far more nuanced account of EU interest representation than a focus upon resources, or treatment of 'business' as if it were a homogenous actor. The procedures to structure dialogue between EU institutions and civil society reinforce an essentially pluralistic system in which EU decision making is highly fragmented. There may be implementation deficits in some of the procedures - most notably the answerability of the Commission to consultation results - but this is part of a system in which EU institutions dominate the policy-making process, insulating themselves from pressure by outside interests, or carefully selecting alliance partners to achieve their policy goals. In this open and structured dialogue, input is a 'voice but not a vote.' The procedures are a work in progress, but since their introduction from 2001 there have been incremental improvements to throughput legitimacy as a result of internal evaluations (Kröger, this volume) and external (Ombudsman, NGOs) watchdogs. They provide for an elite dialogue between EU institutions and largely Brussels based organisations, but in an environment where NGOs can raise the contention of issues and bring wider participation. 


\section{$\underline{\text { References }}$}

Ariès Q \& Panichi J (2015) 'Inside the EU’s palaces of protest’, Politico, http://www.politico.eu/article/europes-activism-lobbyists-institutions-ngos-civilsociety/ accessed on 26 August 2016.

Boräng, F and Naurin, D (2015) 'Try to see it my way!' Frame congruence between lobbyists and European Commission officials, Journal of European Public Policy, 22, 4: 499-515

Bouza Garcia, L. and Greenwood, J. (2014) 'The European Citizens’ Initiative: a new sphere of EU politics?' Interest Groups \& Advocacy, 3: 246-267

Broscheid, A and Coen, D (2007) 'Lobbying Activity and fora Creation in the EU: empirically exploring the nature of the public good, Journal of European Public Policy, 14, 3: 346-365.

Crespy, A (2014) 'Deliberative Democracy \& the Legitimacy of the EU: a reappraisal of conflict', Political Studies, 62: 81-98.

Dür A, Bernhagen P \& Marshall D (2015) 'Interest Group Success in the EU: how and why do business lose?’ Comparative Political Studies, 48, 8: 951-983

Dür A \& Mateo G (2014) 'Public Opinion \& Interest Group Influence: how citizen groups derailed the Anti-Counterfeiting Trade Agreement', Journal of European Public Policy, 21: 8, 1199-1217.

ECORYS (2007) 'A Voice, Not a Vote: Evaluation of the civil society dialogue at DG Trade', http://trade.ec.europa.eu/doclib/docs/2007/march/tradoc_133527.pdf accessed on 29 August 2016.

European Commission (2001) White Paper on Governance http://eur-lex.europa.eu/legal-content/EN/TXT/?uri=URISERV:110109 accessed on 22 August 2016. 


\section{European Commission (2015) REPORT FROM THE COMMISSION}

on the application in 2014 of Regulation (EC) No 1049/2001 regarding public access to European Parliament, Council and Commission documents, Brussels, 6.8.2015 COM(2015) 391 final, http://ec.europa.eu/transparency/regdoc/rep/1/2015/EN/12015-391-EN-F1-1.PDF accessed on 23 August 2016.

Gehlen, C (2006) 'Lobbying in Brussels: the EU Directive on the Patentability of Computer Implemented Inventions', European Case Clearing House case number 206-062-1

Gornitzka, A and Sverdrup, U (2015) Societal Inclusion in Expert Venues:

Participation of Interest groups and business in the European Commission Expert Groups, Politics \& Governance, 3, 1, 151-165.

Greenwood, J and Dreger, J (2013) 'The Transparency Register: a strong vanguard of European lobby regulation?' Interest Groups \& Advocacy, 2, 2:139-162.

Greenwood, J and Tuokko, K (2016) 'The European Citizens’ Initiative: the territorial extension of a European Political Public Sphere?’ European Politics \& Society, 17, 4,

Inter-Institutional Agreement on the Transparency Register http://www.europarl.europa.eu/sides/getDoc.do?pubRef=-//EP//TEXT+TA+P7-TA2014-0376+0+DOC+XML+V0//EN accessed on 29 August 2016.

Iusman, I and Boswell, J (2016) 'The dilemmas of pursuing 'throughput legitimacy' through participatory measures', West European Politics, http://dx.doi.org/10.1080/01402382.2016.1206380 accessed on 29 August 2016.

Jacquot, S and Vitale, T (2014) Law as weapon of the weak? A comparative analysis of legal mobilization by Roma and women's groups at the European level, Journal of European Public Policy, 21, 4: 587-604. 
Klüver H, Braun C \& Beyers J (2015) 'Legislative lobbying in context: towards a conceptual framework of interest group lobbying in the European Union', Journal of European Public Policy, 22:4, 447-461.

Kohler Koch, B (2012) Post-Maastricht Civil Society and Participatory Democracy, Journal of European Integration, 34, 7: 809-824.

Kohler Koch, B (2013) De-mystification of participatory democracy: EU governance and civil society (Oxford: Oxford University Press).

Leiren, M \& Parks, L (2014) When trade unions succeed: Cases of blocked liberalisation in the common market, European Journal of Political Research, 53, 3: 465-479.

Mandelkern Report (2001) Mandelkern Group on Better Regulation Final Report of 13 November 2001.

http://ec.europa.eu/smart-

regulation/better_regulation/documents/mandelkern_report.pdf

Official Journal of the European Communities (1993) An Open and Structured Dialogue between the Commission and Special Interest Groups, 93/C/63/02, http://eur-lex.europa.eu/legalcontent/EN/TXT/PDF/?uri=OJ:C:1993:063:FULL\&from=en accessed on 22 August 2016.

Panichi, J (2015) ‘Commission agrees to boost revolving door transparency’, Politico, 14.12.15, http://www.politico.eu/article/commission-agrees-to-boost-revolving-doortransparency-lobbying-juncker-ombudsman/ accessed on 29 August 2016

Parks, L (2015) Social Movement Campaigns on EU Policy (Basingstoke: Palgrave Macmillan). 
Schmidt, V (2012) 'Democracy and Legitimacy in the EU revisited: Input, Output and Throughput', Political Studies, 61, 1: 2-22.

Smismans, S and Minto, R (2016) 'Are integrated impact assessments the way forward for mainstreaming in the European Union?’ Regulation \& Governance, http://onlinelibrary.wiley.com/doi/10.1111/rego.12119/epdf accessed on 29 August 2016.

Toor, A (2016) Europe's net neutrality guidelines seen as a victory for the open web, The Verge, 30.8.2016, http://www.theverge.com/2016/8/30/12707590/eu-netneutrality-rules-final-guidelines-berec?ftcamp $=$ crm/email//nbe/BrusselsBrief/product

Transparency International (2015) ‘Lobbying in Europe: Hidden Influence, Privileged Access, http://www.transparencyinternational.eu/wpcontent/uploads/2015/04/Lobbying_web.pdf Accessed on 29 August 2016

van de Steeg, M (2010) 'Theoretical Reflections on the Public Sphere in the European Union; A Network of Communication or a Political Community?' in C Bee and E Bozzini (eds.) 'Mapping the European Public Sphere: institutions, media and civil society’ (Aldershot: Ashgate), pp.31-46.

Von der Berchard, H (2016) The man who killed TTIP, Politico, 14 July 2016, http://www.politico.eu/article/the-man-who-killed-ttip-thilo-bode-foodwatchgermany-free-trade/ accessed on 30 August 2016

Woll, C (2012) 'The brash \& the soft-spoken: Lobbying styles in a transatlantic comparison’, Interest Groups \& Advocacy, 1, 2: 193-214.

Young, A R (2010) 'The Politics of Regulation and the Internal Market', in K E Jørgensen, M A Pollack and B Rosamond (eds.) Handbook of European Union Politics (London: Sage), pp373-394. 
i Friends of the Earth Europe, http://www.foeeurope.org/ accessed on 23 August 2016. 